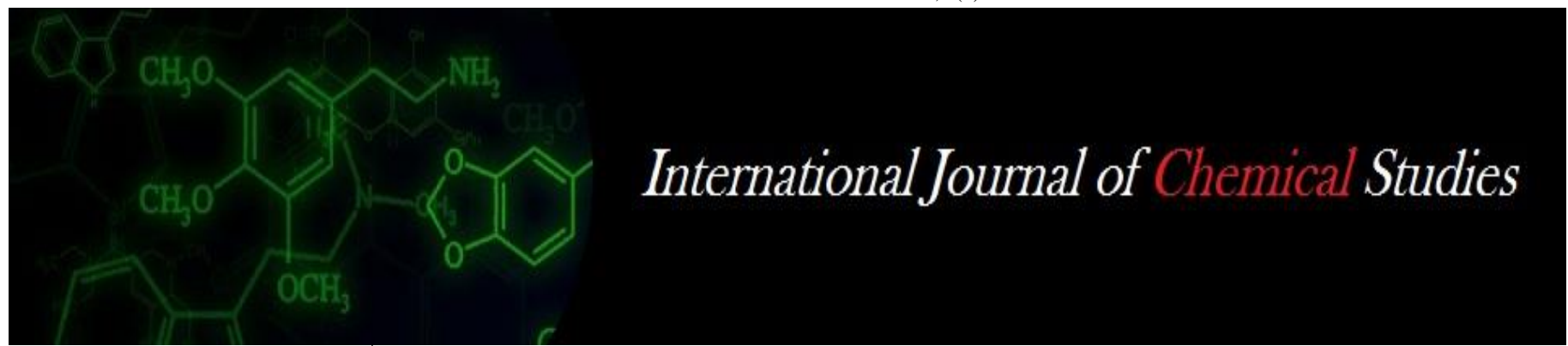

P-ISSN: 2349-8528

E-ISSN: 2321-4902

www.chemijournal.com

IJCS 2020; 8(3): 53-56

(C) 2020 IJCS

Received: 26-03-2020

Accepted: 28-04-2020

Bhagyashree Singh

Sai Nath University, Ranchi,

Jharkhand, India

RB Singh

N.D. University of Agriculture

and Technology Kumarganj,

Faizabad, Uttar Pradesh, India

Prashant Kumar Singh

ITM University, Gwalior,

Madhya Pradesh, India
Corresponding Author: Bhagyashree Singh

Sai Nath University, Ranchi, Jharkhand, India

\section{Study on the resistance inducing chemicals against the Alternaria blight disease in linseed in in vivo}

Bhagyashree Singh, RB Singh and Prashant Kumar Singh

DOI: https://doi.org/10.22271/chemi.2020.v8.i3a.9465

Abstract

Linseed is one of the major Rabi oilseed crop of India. It is grown in Madhya Pradesh, Uttar Pradesh, Maharashtra, Jharkhand, Chhattisgarh and Bihar. In the country Madhya Pradesh and Uttar Pradesh together contribute to the national linseed production to the extent of about $70 \%$. It is one of the oldest crops cultivated for seed and fiber. Among the various factors responsible for lowering down its yield Alternaria blight caused by Alternaria lini is considered to be the major one. The efforts were made to search efficacious and cheaper resistance inducing chemicals as compare to fungicide under field condition for the management of the disease. Field experiments were conducted at the University Experiment Station at Kumarganj (Faizabad) Uttar Pradesh during rabi 2011-12 \& 2012-13 seasons following recommended agronomic practices including nutrient management i.e. $80 \mathrm{Kg} \mathrm{N}, 40 \mathrm{Kg} \mathrm{P}$, $40 \mathrm{Kg} / \mathrm{ha}$. The cultivar 'Shekhar' was sown on 25 October in randomized block design having $4 \mathrm{~m} \times 3 \mathrm{~m}$ plot size with $30 \times 10 \mathrm{~cm}$ plant spacing in three replications. The effectiveness of different resistance inducing chemicals viz. Benzoic acid, Napthelic acetic acid, Salicylic acid, Phosphoric acid, Isnicotinic acid at 0.05 and $0.1 \%$ concentration along with fungicide Mancozeb @ $0.25 \%$ were tested against the disease severity and seed yield of the crop Minimum disease $(28.40 \%)$ severity with maximum yield $\mathrm{T}_{10}$ $(724.16 \mathrm{~kg} / \mathrm{ha})$ was recorded with spraying of Salicylic acid @ $0.10 \%$ followed by the same chemical @ $0.05 \%$ and Benzoic acid @ 0.10\% respectively. But maximum benefit cost ratio was recorded with Benzoic acid@0.05\%.

Keywords: In vivo, chemicals, Alternaria lini, Percent disease intensity, Linseed

\section{Introduction}

Linseed (Linum usitatissimum L.) is a multipurpose crop and is grown in India mainly for oil, whereas in western countries, it is grown especially for fiber. There are different varieties of linseed meant for both purposes. This crop has many industrial and medicinal values in addition to its direct food value. Linseed (Linum usitatissimum L.) $(2 \mathrm{n}=30)$ belongs to the family Linaceae and the genus Linum, which has 100 species. Linum usitatissimum Linn is commercially the most important one. It is commonly known as "Ulsee" or "Tisee". Globally linseed is an important crop and its production is $21.23 \mathrm{lac}$ tones from $21.12 \mathrm{lac} / \mathrm{ha}$ with an average yield of $1006 \mathrm{~kg} / \mathrm{ha}$. While our national production is 1.54 lac tonnes from an area of 3.42 lac ha with poor productivity of $449 \mathrm{~kg} / \mathrm{ha}$. India ranks second in area after Canada in the world, but is at fourth place in term of production after Canada, China and U.S.A. In term of productivity India $(449 \mathrm{~kg} / \mathrm{ha})$ is far below to Canada $(1492 \mathrm{~kg} / \mathrm{ha})$, U.S.A $(1484 \mathrm{~kg} / \mathrm{ha})$, Egypt $(1465 \mathrm{~kg} / \mathrm{ha})$, Russia (1292kg/ha) and China (944kg/ha) (Anonymous-2011). The efforts were made to search efficacious and cheaper resistance inducing chemicals as compare to fungicide under field condition for the management of the disease.

\section{Materials and methods}

Field experiments were conducted at the University Experiment Station at Kumarganj $\left(26^{\circ} 47^{\prime} \mathrm{N}, 82^{\circ} 12^{\prime} \mathrm{E}, 113 \mathrm{~m}\right.$ mean sea level), Faizabad, Uttar Pradesh during rabi 2011-12 \& 2012-13 seasons following recommended agronomic practices including nutrient management i.e. $80 \mathrm{Kg} \mathrm{N}, 40 \mathrm{Kg} \mathrm{P}, 40 \mathrm{Kg} / \mathrm{h}$. The cultivar 'Shekhar' was sown on 25 October in randomized block design having $4 \mathrm{~m} \times 3 \mathrm{~m}$ plot size with $30 \times 10 \mathrm{~cm}$ plant spacing in three replications. 
The effectiveness of different resistance inducing chemicals viz. Benzoic acid, Napthelic acetic acid, Salicylic acid, Phosphoric acid, Isonicotinic acid at 0.05 and $0.1 \%$ concentration along with fungicide Mancozeb @ $0.25 \%$ were tested against the disease severity and seed yield of the crop. Spraying of chemicals was initiated after 30 days of sowing as prophylactic spray. Second spray was given at disease initiation .The required amount of each chemicals were first dissolved in few $\mathrm{ml}$ of ethanol and then mixed with requisite amount of water and sprayed with knap-sap sprayer of 10 liter capacity. The crop was regularly observed for first appearance of disease. The disease severity in each treatment was recorded 10 days after first spraying and at prematurity stage using $0-5$ point scale $(0=$ Disease free; $1=\mathrm{Up}$ to $10 \%$ leaf area infected; $2=>10.1 \%$ to $25 \%$ leaf area infected; $3=$ $>25.1 \%$ to $50 \%$ leaf area infected; $4=>50.1 \%$ to $75 \%$ leaf area infected; and $5=>75 \%$ leaf area infected and the per cent disease intensity (PDI) was calculated as per formula (Eq. 1) given below:

$$
\mathrm{PDI}=\frac{\text { Sum of total numerical rating }}{\text { Total number of leaves examined }} \times \frac{100}{\text { maxımum-grade }}
$$

Seed yield/ plot were recorded in each treatment separately to see the difference in yield between treated and control condition and yield/hectare was calculated. Test weight of seed of each treatment was recorded as g/1000 seeds. The benefit of cost ratio was calculated on the basis of seed yield of each treatment.

\section{Result and Discussion}

A perusal of the table 1.1 indicates that all the treatment significantly reduced the severity of disease on leaves as compared to untreated check. Minimum disease intensity of $29.06 \%$ and $37.47 \%$ were recorded with Salicylic acid $(0.10 \%)$ followed by lower concentration of same chemicals $0.05 \%$ (30.98 and 38.54\%) and Benzoic acid 0.10\% (33.21 and $41.73 \%$ ) respectively during both the years but all were at par. The treatment Benzoic acid $\left(\mathrm{T}_{2}\right)$ was also found statistically of par with treatment $\mathrm{T}_{3}$ (NAA $0.05 \%$ ), $\mathrm{T}_{4}$ (NAA $0.10 \%$ ), $\mathrm{T}_{9}$ (Isonicotoic acid $0.05 \%$ ) and $\mathrm{T}_{11}$ (Mancozeb @ $0.25 \%$ ) during 2011-2012 and with $\mathrm{T}_{3}, \mathrm{~T}_{4}, \mathrm{~T}_{7}, \mathrm{~T}_{8}, \mathrm{~T}_{9}, \mathrm{~T}_{10}$ during
2012-13 respectively. In case of bud damage all the treatment were recorded significantly effective over control (untreated check) during 2011-12, when disease pressure was low but during 2012-13 only treatment $\mathrm{T}_{5}$ (Salicylic acid $0.05 \%$ ) and $\mathrm{T}_{3}$ (NAA $0.05 \%$ ) showed significant superiority is controlling the bud damage over check. Minimum bud damage during both the years were recorded with treatment $\mathrm{T}_{5}$ i.e. spray of Salicylic acid @ $0.05 \%$, it was followed by the treatment $\mathrm{T}_{4}$ (NAA $0.10 \%$ ) and $\mathrm{T}_{3}$ (NAA $0.05 \%$ ) during 2011-2012 and treatment $\mathrm{T}_{3}$ and $\mathrm{T}_{2}$ during 2012-13 respectively. Maximum disease severity (PDI 44.54 and 56.29) and bud damage (29.33 and $39.22 \%$ ) were recorded in untreated plots during both the years. All the treatment significantly increased the seed yield as compared with untreated check except treatment $\mathrm{T}_{8}$ (Phosphoric acid @0.10\%) and $\mathrm{T}_{9}$ (Isonicotonic acid @ $0.05 \%$ ) Maximum yield of $749.99 \mathrm{~kg} / \mathrm{ha}$ and $783.33 \mathrm{~kg} / \mathrm{ha}$ was recorded with spraying of Salicylic acid @0.10\% during both years. It was followed by the treatment $\mathrm{T}_{2}$ (Sprays of Benzoic acid @0.10\%) and $\mathrm{T}_{1}$ (Sprays of Benzoic acid @ $0.05 \%$ ) during first year and treatment $\mathrm{T}_{10}$ (Sprays of Isonicotonic acid @0.10\%) and $\mathrm{T}_{2}$ during second year respectively. All there treatment were found statistically at par among themselves. Minimum yield (474.99 and $408.33 \mathrm{~kg} / \mathrm{ha}$ ) was recorded in check plots. On mean basis of both the years. Maximum seed yield was recorded by $\mathrm{T}_{10}(724.16 \mathrm{~kg} / \mathrm{ha})$ and $\mathrm{T}_{2}(719.22 \mathrm{~kg} / \mathrm{ha})$ respectively. Maximum test weight $(1000$ seed weight) was recorded with treatment) $\mathrm{T}_{1}(0.05 \%$ of Benzoic acid) during both the years. It was followed by treatments $\mathrm{T}_{10}$ first year while during second years no significant difference was noted among the treatments and check.

Yield loss with different treatments on mean basis was avoided from 19.61 to 42.35 maximum being with spraying of Salicylic acid $(0.10 \%)$. It was again followed by treatment $\mathrm{T}_{10}$ (38.98) and $\mathrm{T}_{2}(38.56 \%)$ respectively. Test weight loss was also avoided by the treatment from $1.34\left(\mathrm{~T}_{5}\right)$ to 10.15 Per cent $\left(\mathrm{T}_{1}\right)$.

Maximum net return of Rs $8168.34 /$ ha with benefit cost ratio of 5.60 was recorded with $\mathrm{T}_{2}$ (Benzoic acid $0.10 \%$ ) followed by treatment $\mathrm{T}_{6}$ (salicylic $0.10 \%$ ) but maximum benefit was recorded with lower doses of Benzoic acid (7.10) and Salicylic acid (4.8) respectively.

Table 1: Effectiveness of resistance inducing chemicals against severity of Alternaria blight disease in linseed CV Shekhar during 2011-2012 and 2012-2013

\begin{tabular}{|c|c|c|c|c|c|c|c|c|}
\hline \multirow{2}{*}{ Treatments } & \multicolumn{4}{|c|}{ Seed yield (kg/ha) } & \multicolumn{4}{|c|}{ Test weight(g) } \\
\hline & 2011-2012 & 2012-2013 & mean & Avoidable loss \% & 2011-2012 & 2012-2013 & mean & Avoidable loss \% \\
\hline $\mathrm{T}_{1}$ Benzoic acid $0.05 \%$ & 716.66 & 666.66 & 691.66 & 36.10 & 9.03 & 8.90 & 5.96 & 10.15 \\
\hline $\mathrm{T}_{2}$ Benzoic acid $0.10 \%$ & 743.99 & 694.44 & 719.22 & 38.56 & 8.33 & $8.33 \mathrm{ss}$ & 8.30 & 3.01 \\
\hline $\mathrm{T}_{3}$ NAA $0.05 \%$ & 641.66 & 624.99 & 633.33 & 30.22 & 8.50 & 8.10 & 8.25 & 2.42 \\
\hline $\mathrm{T}_{4}$ NAA $0.10 \%$ & 699.99 & 658.33 & 679.16 & 34.93 & 8.50 & 8.40 & 8.45 & 4.73 \\
\hline $\mathrm{T}_{5}$ Salicylic acid $0.05 \%$ & 678.32 & 649.99 & 664.16 & 33.46 & 8.13 & 8.20 & 8.16 & 1.34 \\
\hline $\mathrm{T}_{6}$ Salicylic acid $0.10 \%$ & 749.99 & 783.33 & 766.66 & 42.35 & 8.40 & 8.10 & 8.25 & 2.42 \\
\hline T7 Phosphoric acid $0.05 \%$ & 699.99 & 641.66 & 670.82 & 34.12 & 8.77 & 8.40 & 8.60 & 6.39 \\
\hline T8 Phosphoric acid $0.10 \%$ & 599.99 & 508.33 & 554.16 & 20.26 & 8.93 & 8.50 & 8.70 & 7.47 \\
\hline T9Isonicotonicacid $0.05 \%$ & 583.33 & 516.06 & 549.69 & 19.61 & 8.67 & 8.40 & 8.50 & 5.20 \\
\hline $\mathrm{T}_{10}$ Isonicotonicacid 0.10 & 698.33 & 749.99 & 742.16 & 38.98 & 8.93 & 8.50 & 8.70 & 7.47 \\
\hline $\mathrm{T}_{11}$ mancozeb @0.25\% & 699.99 & 649.99 & 674.99 & 34.53 & 9.03 & 8.10 & 8.56 & 5.95 \\
\hline $\mathrm{T}_{12}$ Control & 474.99 & 408.83 & 441.91 & - & 7.90 & 8.20 & 8.05 & - \\
\hline GM & 498.88 & 682.82 & - & - & 8.58 & 8.34 & - & - \\
\hline Sem \pm & 59.99 & 45.83 & - & - & 0.278 & 0.311 & - & - \\
\hline $\mathrm{CD}$ at $5 \%$ & 165.83 & 143.32 & - & - & 0.815 & 0.911 & - & - \\
\hline
\end{tabular}


Table 2: Effect of chemicals on seed yield and test weight of linseed CV Shekhar during 2011-2012 and 2012-2013

\begin{tabular}{|c|c|c|c|c|c|c|}
\hline \multirow[t]{2}{*}{ Treatments } & \multicolumn{2}{|c|}{\begin{tabular}{|c|} 
2011-2012 Severity of disease on \\
leaves (PDI)
\end{tabular}} & \multirow{2}{*}{$\begin{array}{c}\text { Bud damage } \\
(\%)\end{array}$} & \multicolumn{2}{|c|}{$\begin{array}{c}\text { 2012-2013 Severity of disease on } \\
\text { leaves (PDI) }\end{array}$} & \multirow[t]{2}{*}{ Bud damage (\%) } \\
\hline & After I st spray & After II nd spray & & After I st spray & After II nd spray & \\
\hline $\mathrm{T}_{1}$ Benzoic acid $0.05 \%$ & $13.27(21.30)$ & $31.27(34.27)$ & $27.00(31.23)$ & $15.80(23.42)$ & $45.87(42.53$ & $30.33(33.13)$ \\
\hline $\mathrm{T}_{2}$-Benzoic acid $0.10 \%$ & $14.20(22.06)$ & $30.00(33.21)$ & $24.67(29.75)$ & $16.00(23.58)$ & $44.53(41.73)$ & $28.33(32.08)$ \\
\hline $\mathrm{T}_{3}$-NAA $0.05 \%$ & $15.47(23.34)$ & $33.67(33.49)$ & $29.67(32.97)$ & $17.60(24.88)$ & $46.40(42.94)$ & $25.33(30.15)$ \\
\hline T4-NAA $0.10 \%$ & $17.80(24.95)$ & $33.67(33.49)$ & $24.33(29.50)$ & $20.60(27.06)$ & $46.93(42.88)$ & $30.00(33.16)$ \\
\hline $\mathrm{T}_{5}$-Salicylic acid $0.05 \%$ & $15.80(23.42)$ & $26.53(30.98)$ & $22.67(28.40)$ & $13.80(21.81)$ & $39.53(38.54)$ & $20.00(26.07)$ \\
\hline $\mathrm{T}_{6}$-Salicylic acid $0.10 \%$ & $11.40(19.73)$ & $23.60(29.06)$ & $31.67(34.20)$ & $12.07(20.27)$ & $37.07(37.47)$ & $30.33(33.38)$ \\
\hline $\mathrm{T}_{7}$-phosphoric acid $0.05 \%$ & $21.10(27.28)$ & $37.60(37.88)$ & $35.00(36.26)$ & $21.60(27.76)$ & $54.67(47.67)$ & $36.66(37.15)$ \\
\hline $\mathrm{T}_{8}$-Phosphoric acid $0.10 \%$ & $22.40(28.25)$ & $36.80(37.85)$ & $35.00(36.23)$ & $21.23(27.42)$ & $50.03(45.00)$ & $28.00(31.64)$ \\
\hline T9-Isonictonic acid $0.05 \%$ & $17.67(24.80)$ & $37.87(37.58)$ & $35.00(36.27)$ & $22.30(28.18)$ & $53.93(45.52)$ & $30.33(33.29)$ \\
\hline $\mathrm{T}_{10}$-Isonictonic acid $0.10 \%$ & $21.67(27.76)$ & $31.60(34.58)$ & $29.67(32.95)$ & $19.87(26.42)$ & $40.33(33.35)$ & $20.33(32.09)$ \\
\hline $\mathrm{T}_{11-M a n c o z e b} @ 0.25 \%$ & $20.73(26.78)$ & $37.20(37.58)$ & $29.87(33.03)$ & $21.20(27.42)$ & $48.80(44.31)$ & $31.00(33.35)$ \\
\hline $\mathrm{T}_{12}$-Control & $22.60(28.38)$ & $49.27(33.35)$ & $40.33(33.35)$ & $24.00(29.33)$ & $69.20(56.29)$ & $40.00(39.22)$ \\
\hline $\mathrm{Gm}$ & $17.84(24.88)$ & $34.26(35.62)$ & 32.62 & $18.83(25.70)$ & $48.16(43.91)$ & 32.90 \\
\hline SEm \pm & 1.62 & 1.51 & 0.902 & 1.80 & 1.73 & 3.020 \\
\hline $\mathrm{CD}$ at $\overline{5 \%}$ & 4.78 & 4.47 & 2.646 & 5.33 & 5.13 & 8.58 \\
\hline
\end{tabular}

Table 3: Economics of the chemical treatments for the management of Alternaria blight in linseed during 2011-2012

\begin{tabular}{|c|c|c|c|c|c|}
\hline Treatments & $\begin{array}{c}\text { Additional yield over control } \\
\text { (kg/ha) }\end{array}$ & $\begin{array}{c}\text { Additional income } \\
\text { (Rs/ha) }\end{array}$ & \begin{tabular}{|c|}
$\begin{array}{c}\text { Cost of protection } \\
\text { (Rs/ha) }\end{array}$ \\
\end{tabular} & $\begin{array}{l}\text { Net return } \\
\text { (Rs/ha) }\end{array}$ & $\begin{array}{l}\text { Benefit cost } \\
\text { ratio }\end{array}$ \\
\hline $\mathrm{T}_{1}$ Benzoic acid $0.05 \%$ & 241.67 & 8458.45 & 1043.33 & 7415.12 & 7.10 \\
\hline $\mathrm{T}_{2}$ Benzoic acid $0.10 \%$ & 275.00 & 9625.00 & 1456.66 & 8168.34 & 5.60 \\
\hline T 3 NAA $0.05 \%$ & 166.67 & 5833.45 & 7296.00 & -1462.55 & -0.20 \\
\hline T4 NAA $0.10 \%$ & 225.00 & 7875.00 & 13963.00 & -6088.00 & -0.40 \\
\hline T5 Salicylic acid $0.05 \%$ & 203.33 & 7105.00 & 1225.00 & 5880.00 & 4.8 \\
\hline T6 Salicylic acid $0.10 \%$ & 275.00 & 9625.00 & 1820.00 & 7805.00 & 4.29 \\
\hline $\mathrm{T}_{7}$ Phosphoric acid $0.05 \%$ & 225.00 & 7875.00 & 1270.00 & 6605.00 & 5.2 \\
\hline $\mathrm{T}_{8}$ Phosphoric acid $0.10 \%$ & 125.00 & 4375.00 & 1910.00 & 2465.00 & 1.29 \\
\hline $\mathrm{T}_{9}$ Isonicotoic acid $0.05 \%$ & 108.34 & 3791.90 & 4413.00 & -621.1 & -0.14 \\
\hline $\mathrm{T}_{10}$ Isonicotoic acid $0.10 \%$ & 183.34 & 6416.90 & 8196.00 & 1774.1 & -0.22 \\
\hline T11 Mancozeb@0.25\% & 225.00 & 7875.00 & 2230.00 & 5645.00 & 2.53 \\
\hline
\end{tabular}

\section{Discussion}

The efforts have been made to find out the effectiveness of resistance inducing chemicals for the management of Alternaria blight disease of linseed crop in sick plot. A perusal of the table indicates that all the treatment significantly reduced the severity of disease on leaves as compared to untreated check. Minimum disease intensity of $29.06 \%$ and $37.47 \%$ were recorded with Salicylic acid $(0.10 \%)$ followed by lower concentration of same chemical $0.05 \%$ (30.98 and 38.54\%) and Benzoic acid 0.10\% (33.21 and $41.73 \%$ ) respectively during both the years but all were at par. In case of bud damage all the treatments were recorded significantly effective over control (untreated check) during 2011-12, when disease pressure was low but during 2012-13 only treatment $\mathrm{T} 5$ (Salicylic acid $0.05 \%$ ) and $\mathrm{T}_{3}$ (NAA $0.05 \%$ ) showed significant superiority in controlling the bud damage over check. Maximum test weight (1000 seed weight was recorded with treatment) $\mathrm{T}_{1}(0.05 \%$ of benzoic acid $)$ during both the years. It was followed by treatments $\mathrm{T}_{10}$ during second years no significant difference was noted among the treatments and check) Maximum net return of Rs $8168.34 /$ ha with benefit cost ratio of 5.60 was recorded followed by treatment $\mathrm{T}_{6}$ (salicylic $0.10 \%$ ) but maximum benefit was recorded with lower doses of Benzoic acid (7.10) and salicylic acid (4.8). Concurrent with present finding, Singh and Singh reported maximum effective NAA followed by Salicylic acid against Alternaria blight of linseed. Singh (2007) ${ }^{[4]}$ reported the management of Alternaria blight in linseed with plant growth activator namely salicylic, BION (CGA 245704) and Phosphoric acid and fungicide Indofil M45. It showed phytotoxic effect. Prophylatic sprays (30 and 45
DAS after planting) of Salicylic acid were superior over spray after disease appearance. Singh et al. (2004) ${ }^{[2]}$ also reported the affectivity of salicylic acid against Alternaria brassicae causing blight disease mustard, while Singh and Singh reported maximum effective NAA followed by Salicylic acid against Alternaria blight of linseed. Sunjula et al. (2010) have reported effectiveness of Salicylic acid with combination of benzothiadiazole in defense mechanism by increasing peroxidase activity and Phenolic content in the host against the Alternaria brassicae.

\section{Conclusion}

In both year (2011- 12 \& 2012-13) Maximum reduction in disease severity with increased yield was recorded with the two sprays of Salicylic acid @ $0.10 \%$ followed by $0.05 \%$ concentration of same chemicals and Benzoic acid 0.10 per cent., respectively, but all were at par, whereas maximum benefit cost ratio was recorded with spraying of Benzoic acid $(0.05 \%$ and $0.10 \%)$.

\section{Acknowledgement}

The authors thank the Department of Plant Pathology of College of Agriculture NDUAT Faizabad (U.P.) for providing the necessary facilities.

\section{Reference}

1. Anonymous. Annual Report: 2010-11, Linseed P.C unit (Linseed) C.S.A.U.A \& T Kanpur, 2011, 272.

2. Singh R.B, Singh R.N. Occurrence and management of Alternaria blight of linseed in eastern India Pl Dis Res. 2004; 19:120-124. 
3. Singh R.B, Singh H.K. Evaluation of resistance inducing chemicals against Alternaria Blight of Linseed Indian Phytopath. 2006; 59(3):366-367.

4. Singh R.B, Singh R.N. Integrated management of blight of linseed caused by Alternaria spp Indian J Agric Sci. 2007; 77(1):55-58. 